\title{
Fra omsorg til service - nyorientering i hjemmeplejen via frit valg?
}

\author{
LEENA ESKELINEN, EIGIL BOLL HANSEN \& \\ MORTEN FREDERIKSEN
}

Hvordan vil frit valg afleverandør på hjemmehjoelpsområdet påvirke hjoelpens indhold og orientering? Med udgangspunkt i begreberne omsorg og service saetter artiklen fokus på disse begrebers gennemslag i praksis, brugernes og de professionelles rolle i den nye organisering samt de forventede konsekvenser for hjoelpens udformning.

\section{Indledning}

Såvel indholdet som omfanget af hjemmeplejens ydelser har de seneste år været under forandring i alle de nordiske lande. Det skyldes bl.a. ændringer i hjemmeplejens organisering som følge af en øget markedsgørelse og privatisering af hjemmeplejen.

Leena Eskelinen, ph.d. i psykologi og docent i socialt arbejde, Eigil Boll Hansen, cand.oecon. og docent i ældreforskning og Morten Frederiksen, socialrådgiver og stud.scient.soc., arbejder i AKF, Amternes og Kommunernes Forskningsinstitut i København og har sammen gennemført en undersøgelse af frit valg på ældreområdet.
I Danmark trådte den såkaldte fritvalgsordning i kraft 1. januar 2003, hvilket betyder, at kommunerne er forpligtet til at åbne markedet for private leverandører, der opfylder kommunens kvalitetskrav. Fritvalgsordningen er en organisatorisk omstilling fra en enhedsorganisation til en struktur med flere aktører, hvilket medfører nye mekanismer, hvorigennem hjemmehjælpens indhold formes. Fritvalgsordningen aktualiserer spørgsmålet om, hvad indholdet af hjælpen skal være, og hvilken rolle henholdsvis modtagere og professionelle har i hjælpens udformning.

Artiklen har to formål. Det ene formål er at belyse, hvordan henholdsvis den kom- 
munale hjemmepleje og private aktører fortolker hjælpens indhold i relation til omsorg og service. Det andet formål er at diskutere, hvorvidt privatisering medfører andre og nye former for hjemmehjælp end hidtil. Vi fokuserer især på den nye rollefordeling mellem brugere og professionelle, som fritvalgsordningen medfører. Dette aspekt er interessant, fordi det er centralt både for definitionen af omsorg og service og for indholdet af lovgivningen om frit valg.

Artiklen tager metodisk afsæt i forskning, der har defineret og diskuteret omsorgsbegrebet og udviklingen heri især i nordisk regi. Den hermed opnåede forståelse af begreberne omsorg og service anvendes til at belyse intentionerne $\mathrm{i}$ den gældende danske lovgivning på området og til at fortolke empirisk materiale fra fire danske kommuner. Kommunerne blev udvalgt til interviewundersøgelsen fra Socialministeriets Fritvalgsdatabase, som indeholder oplysninger om godkendte private leverandører i samtlige danske kommuner. Ved udvælgelsen af de fire kommuner blev der lagt vægt på geografisk beliggenhed (to af kommunerne ligger i Jylland og to på Sjælland) og kommunestørrelse (to mellemstore kommuner med ca. 20.000 indbyggere og to mindre kommuner med mindre end 10.000 indbyggere), og der blev udvalgt kommuner, der ikke før fritvalgsordningens ikrafttræden havde haft private leverandører, men som på interviewtidspunktet havde godkendte private leverandører til både praktisk bistand og til personlig pleje. Med hensyn til tilstedeværelse af private leverandører og brugernes valg af privat leverandør, er det vores vurdering, at de udvalgte kommuner ligner de fleste danske kommuner af den næunte størrelse, som indførte frit valg af leveran$\mathrm{d} ø$, da lovens regler herom trådte i kraft 1 . januar 2003. Fx er andelen, der har valgt privat leverandør, i samme størrelsesorden som gennemsnittet for alle danske kommuner, og de private leverandører varetager primært praktisk bistand (Ankestyrelsen 2004). ${ }^{1}$

I hver af de fire kommuner blev der gennemført personlige interview med repræsentanter for ældreområdet, i alle tilfælde en visitator og dennes leder, som afhængig af kommunens forvaltningsstruktur var socialchef, ældrechef eller sundhedsfaglig konsulent. I tre af de fire kommuner kunne der gennemføres personligt interview med ledere af private leverandører. Blandt de private leverandører blev udvalgt de firmaer, som havde de fleste brugere i kommunen. De interviewede ledere - bortset fra én - repræsenterede mindre private virksomheder overvejende med erfaring

1 Ifølge Ankestyrelsen (2004) har de private aktører ikke en særlig stor andel af markedet i Danmark, og de varetager primært opgaver, der vedrører praktisk bistand. I foråret 2004 kunne $63 \%$ af de danske kommuner tilbyde frit valg til praktisk bistand, mens $42 \%$ kunne tilbyde et valg mellem flere leverandører til personlig pleje. En relativt beskeden andel af hjemmehjælpsmodtagerne havde i foråret 2004 valgt en privat leverandør, heraf langt hovedparten til praktisk bistand. Således havde 2\% af modtagerne af personlig pleje og knap 10\% af modtagerne af praktisk bistand i foråret 2004 en privat leverandør (ekskl. Københavns Kommune). 
med praktisk bistand (se nedenstående oversigt).

Formålet med interviewene var at belyse den organisatoriske tilrettelæggelse af ordningen samt dens indholdsmæssige og økonomiske konsekvenser for hjælpens udformning. Interviewene blev foretaget i foråret 2004, dvs. et til halvandet år efter ordningens indførelse i Danmark. I alle interview har deltaget personer, som har et indgående kendskab til hjemmehjælpsområdet og den daglige tilrettelæggelse af hjælp til brugerne. Forud for interviewene indhentede forskerne information om kommunen og de private leverandører gennem telefoniske kontakter og skriftligt materiale.

\section{Er omsorgsidealet under pres?}

Forskellige definitioner af omsorg og service lægger delvist vægt på forskellige aspekter, men fælles for dem er, at de indeholder en tydelig skelnen mellem de to begreber. Betydningsforskellene mellem de to begreber handler om forskelle på udøverens og modtagerens roller, status og indflydelse samt relationens karakter. I en omsorgsrelation er omsorgsudøveren den, der har mest magt og indflydelse, mens det i servicerelationen er modtageren af service, som har højest status og mest indflydelse (Wærness 1983, 1996). Det er denne asymmetri og forskel i relationen, der afgør, om der er tale om omsorg eller service. Derimod adskiller opgavernes indhold i omsorgsarbejde sig ikke fra personlig service - social omsorg er ifølge Wærness både en praktisk og følelsesmæssig opgave.

Alligevel indeholder begrebet omsorg ofte en forventning om modtagerne af omsorg. Ifølge idéhistorikeren Qvarsell

Oversigt over de gennemførte personlige interview

\begin{tabular}{lcc}
\hline $\begin{array}{l}\text { Kommune (antal } \\
\text { indbyggere) }\end{array}$ & $\begin{array}{c}\text { Repræsentanter for den } \\
\text { kommunale hjemmepleje }\end{array}$ & $\begin{array}{c}\text { Repræsentanter for private } \\
\text { leverandører }\end{array}$ \\
\hline $\begin{array}{l}\text { Kommune A } \\
\text { (ca. 20.000) }\end{array}$ & sundhedsfaglig konsulent, visitator & $\begin{array}{c}\text { leder af privat virksomhed for } \\
\text { praktisk bistand }\end{array}$ \\
$\begin{array}{l}\text { Kommune B } \\
\text { (ca. I 0.000) }\end{array}$ & $\begin{array}{r}\text { ældrechef, visitator, } \\
\text { administrativ medarbejder }\end{array}$ & $\begin{array}{c}\text { leder og medarbejder af privat virk- } \\
\text { somhed for praktisk bistand }\end{array}$ \\
$\begin{array}{l}\text { Kommune C } \\
\text { (ca. 20.000) }\end{array}$ & ældrechef, visitator & $\begin{array}{l}\text { leder af privat virksomhed for prak- } \\
\text { tisk bistand; leder af privat virksom- } \\
\text { hed for personlig pleje }\end{array}$ \\
\hline $\begin{array}{l}\text { Kommune D } \\
\text { (ca. I 0.000) }\end{array}$ & socialchef, visitator & $\begin{array}{c}\text { 'leder af privat virksomhed for prak- } \\
\text { tisk bistand }\end{array}$ \\
$\begin{array}{l}\text { Interviewperso- } \\
\text { ner i alt }\end{array}$ & 9 & 5 \\
\hline
\end{tabular}

${ }^{1}$ Alene telefonisk kontakt; det var ikke muligt at få en aftale om et personligt interview.

Note: Alle interview blev gennemført ved hjælp af en semistruktureret interviewguide, og de blev lydoptaget. De enkelte interview varede $1 \frac{1 / 2-2}{2}$ timer. Desuden blev der interviewet i alt 19 brugere, fem fra hver kommune, hvoraf 12 modtog hjælp fra en privat leverandør og 7 fra den kommunale hjemmepleje.

Eskelinen, Boll Hansen \& Frederiksen: Fra omsorg til service - nyorientering i hjemmeplejen via frit valg? 
(1991) står omsorgsbegrebet - til forskel fra pleje - for en hjælp, som stiler mod at skabe tålelige vilkår for modtageren ud fra den enkeltes forudsætninger uafhængigt af, hvad der betragtes som normalt eller sundt. Begrebet social service er ifølge Qvarsell en forskydning i retning mod, at modtageren af hjælp selv skal bestemme indholdet i den opnåede hjælp. Wærness definerer omsorgsarbejde som hjælp og omsorg til hjælpafhængige, som ikke selv er i stand til at udføre opgaven. Hun opfatter derimod personlig service som tjenester, som udføres for personer, som selv ville kunne udføre arbejdet, og hun placerer dermed servicebegrebet uden for den offentlige hjemmehjælps regi. Dahl (2000), som har analyseret hjemmehjælpernes professionalisme i Danmark i perioden 1943-1995, deler denne opfattelse og fokuserer i sin analyse udelukkende på omsorgsbegrebet. Opdelingen i offentlig omsorg og (privat) personlig service er imidlertid ikke entydig, som bl.a. analysen af servicebegrebet i denne artikel viser.

Omsorgsbegrebet kan kritiseres for at være blevet anvendt som et normativt begreb og et universalistisk ideal for hjemmeplejen. Omsorgens relative karakter er imidlertid i stigende grad kommet i fokus gennem den nyere svenske og norske forskning. Den har vist, at omsorgsidealet langt fra kan realiseres i hverdagspraksis på grund af strukturelle, herunder organisatoriske og økonomiske betingelser for omsorgsarbejdet (bl.a. Szebehely 1995, Eliasson 1996, Christensen 1997). Den nyere forskning har også bidraget til en erkendelse af omsorgens skiftende karakter gennem tiderne. Dahl (2000) fremhæver i denne sammenhæng omsorgsbegrebets historiske forankring, dets varierende betydning, kampen om dets mening og tilblivelsen af nye dimensioner, hvilket den feministisk orienterede omsorgsteori har overset med dens fokus på omsorg per se. Omsorg som praktisk virksomhed er blevet nuanceret bl.a. af Motevasel (2000), som har beskrevet forskellige former for omsorg ved at skelne mellem situationel og kontinuerlig omsorg. Den situationelle omsorg kræver opmærksomhed på modtageren, men strækker sig ikke uden for situationen, hvor handlingen foregår. Den kontinuerlige omsorg strækker sig derimod fra i går over nuet til morgendagen, og den som modtager omsorger findes nærværende i omsorgsgiverens bevidsthed over tid.

I dansk kontekst har omsorg ikke i samme grad været genstand for forskningsmæssig interesse som det har været tilfældet i Sverige og Norge $^{2}$. Hjælp til selvhjælpprincippet har været det dominerende begreb i dansk sammenhæng. Swane (2003) har vist, med udgangspunkt i en analyse af dette princip, at omsorg og hjælp til selvhjælp er to forskellige former for hjælp bl.a. i den forstand, at det aktiverende sigte ofte ikke er muligt at realisere hos ældre, der er stærkt afhængige af andres hjælp (omsorg). Hjælp til selvhjælp er baseret på en forventning om samarbejde og gensidig forpligtelse mellem giver og modtager. Derfor kan hjælp til selvhjælp ikke betegnes som

2 Dahl (2000) er en af de få danske forskere, der har diskuteret omsorgsbegrebet på hjemmehjælpsområdet. I øvrigt er begrebet blevet brugt inden for sygeplejeforskningen (Eriksen 2000, Timm 2000). 
omsorg - hjælpen er i princippet betinget, idet modtagelse af hjælp forudsætter en modydelse.

I den nyeste danske forskning diskuteres, hvilke arbejdskulturer der kendetegner praksis. Swane (2003) har argumenteret for, at hjælp til selvhjælp-princippet med det aktiverende sigte ikke er gennemført i praksis, selv om den har været et centralt princip siden begyndelsen af 1990'erne. Den socialpædagogiske kultur, der lægger op til hjælp til selvhjælp, blev heller ikke identificeret $i$ en ny dansk undersøgelse, som gennem omfattende observationsstudier i 2001-2003 har målt hjemmehjælpernes tidsanvendelse til forskellige opgaver (Schultz-Larsen \& Hanning 2004). I stedet er der tegn på, at en medicinsk-bureaukratisk kultur, hvor opgaverne er instrumentaliserede, standardiserede og regelstyrede, er i fremgang i de danske kommuner, mens den traditionelle omsorgskultur er under pres. Den samme tendens har Lewinter (1999) beskrevet på baggrund af en omfattende kvalitativ undersøgelse. Dahl (2000), med udgangspunkt i en historisk analyse af hjemmehjælpens professionelle udvikling, peger på, at den seneste udvikling er kendetegnet ved at være en produktionskultur med øget styring og udgiftsbevidsthed.

\section{Bevægelse mod serviceorientering}

I takt med den senere tids markedsgørelse og privatisering af hjemmehjælp er begrebet service blevet aktuelt, men forsknings- mæssigt er den kun blevet belyst i meget begrænset omfang inden for hjemmehjælpsforskningen. Flere forskere på området synes at tage afstand fra tiltagende »serviceorientering" uden at nuancere begrebet service (bl.a. Szebehely 2003). Undertonen i denne kritik er en normativ holdning. Dertil kommer, at service typisk ikke defineres på sine egne præmisser, men gennem omsorg.

Den hidtidige omsorgsforskning har betragtet service som en wikke-omsorgsfuld" handling - bl.a. taler Motevasel (2000) om "servicerettet hjælp«. Serviceorientering er ifølge Szebehely (1999) en del af omsorgsarbejdets markedsgørelse og ændring af arbejdsformer. Dette er interessant, idet der er blevet argumenteret for, at omsorg er omsorgsarbejde uafhængigt af, hvilken samfundsmæssig sfære det finder sted i. Det gør bl.a. Dahl (2000), med henvisning til Wærness og Bubeck, og tager dermed afstand fra bl.a. Graham (1993), som har skelnet mellem omsorg og service, hvor service hører til "public service industries« og mangler sådanne kvaliteter som forpligtelse og følelsesmæssig nærhed. I denne sammenhæng er det værd at mærke, at nogle omsorgsforskere opfatter omsorg som et kontekstafhængigt fænomen, som kan udformes og udføres af forskellige, afhængigt af de vilkår, der hersker (bl.a. Eliasson 1995). Det kan fortolkes som udtryk for, at omsorg ikke er en bestemt faggruppes domæne eller ikke forudsætter faglig uddannelse. Begrebet stammer oprindeligt fra familiemæssige relationer, og en del af forskningen forholder sig bl.a. kritisk til professionalisering af omsorg (bl.a. Christensen 1997). 
Typisk bliver begrebet service imidlertid knyttet til hjælp fra det private marked (Grönroos 2000). Således har de markedsinspirerede reformer under 1990'erne medført en ny sprogbrug og nye fortolkningsrammer i den offentlige sektor (Rombach 1997, Vabø 2003). I serviceterminologien omtales modtagere af hjælp som »kunder" eller "forbrugere». Der er en række behov, som i almindelighed har betydning for forbrugernes oplevelse af servicekvalitet, bl.a. pålidelighed, lydhørhed, sikkerhed og indlevelse (Zeithaml et al. 1990). Service forudsætter ikke nødvendigvis en forpligtende eller gensidig relation mellem modtager og giver. Service bygger på aftaler og bestillinger, hvor servicemodtager typisk har en betydelig indflydelse på opgavens udførelse. Servicebestilleren - forskelligt fra omsorgstager - er ifølge de fleste definitioner overlegen i status og kan derfor tage imod mere end man selv præsterer (Wærness 1983). Den senere forskning har udbygget beskrivelsen af relationen mellem modtager og giver og bl.a. henledt opmærksomheden på, hvordan forhold hos modtager som tilhørsforhold til en bestemt socialklasse og graden af afhængighed af hjælp præger relationen henholdsvis i retning af service eller omsorg (Christensen 1991, Szebehely 1995). Typisk opfattes servicemodtageren som en person, som har overskud og kompetence til at prioritere og vælge $-d v s$. service identificeres med de stærkeste, mens omsorg identificeres med de svageste.

Derfor et det nærliggende at stille spørgsmålet, om serviceorientering fortrænger noget centralt ved omsorg. Er der behov for begrebet service, fordi der er tale om en ny form for hjemmehjælp, eller er service blot et udtryk for omsorgens mange variationer ligesom der har været forskellige idealer for omsorg historisk set? Vi betragter i det følgende, hvordan serviceorientering kommer til udtryk i den nye lovgivning og gennem henholdsvis de kommunale og private virksomhedslederes beskrivelser af hjælpen på baggrund af deres respektive erfaringer med praktisk bistand.

\section{Frit valg og socialpolitiske principper}

Frit valg af leverandør af praktisk bistand og personlig pleje blev indført i Danmark med det formål at saette borgeren $i$ centrum og skabe bedre rammer for en oeldrepolitisk indsats baseret på kontinuitet, selvstoendighed, voerdighed og respekt for de oeldre og for deres individuelle ønsker og behov. Et andet vigtigt formål med indførelse af frit valg af leverandør var at skabe øget konkurrence om leveringen af ydelserne i hjemmeplejen, dvs. øget effektivitet og kvalitet (Socialministerens bemærkninger ved fremsættelse af lovforslaget $L$ 130, 2002).

I lovgivningen til fritvalgsordningen lægges således på den ene side vægt på det politisk-administrative systems målrationalitet og på den anden side brugernes interesser og medindflydelse. Kvalitetssikring vil dels ske gennem konkurrence, dels ved at kvalitetsopfølgningen ligger hos den enkelte bruger. Personalets rolle er derimod ubeskrevet og udefineret i lovgrundlaget - bortset fra, at udføreren af hjemmehjælpsopgaver ifølge fritvalgsordningen skal rette sin opmærksomhed mod brugerens 
og bestillerens ønsker og tilkendegivelser. Derfor må medarbejderne forventes at arbejde ud fra, hvad man kan kalde serviceprincipper, hvor kundens tilfredshed er den vigtigste målestok: "Det er således regeringens overbevisning, at ikke mindst den mulighed for individuelle løsninger, der skabes med forslagene om frit valg, vil give større tilfredshed blandt de oeldre." Den nye markedsorienterede organisering af hjemmehjælpen synes at betyde et skift i hjælpens indhold og orientering mod en kompenserende indsats.

Frit valg er en del af Lov om social service, hvor hjælpen defineres med termer, som understreger forebyggende og aktiverende elementer samt modtagerens deltagelse og medansvar. Det anføres, at formålet med indsatsen til voksne med nedsat fysisk eller psykisk funktionsevne er at forebygge, at problemer forværres, at forbedre den enkeltes sociale og personlige funktion, at forbedre mulighederne for den enkeltes livsudfoldelse og at yde en helhedsorienteret indsats afpasset den enkeltes behov ( $\$ 67)$. I vejledningen til den sociale servicelov (Socialministeriet 1998) fremhæves under overskriften hjoelp til selvhjoelp et aktiverende sigte med hjælpen. Hjælpen bør have som primært mål at gøre modtageren i stand til at klare sig selv, eller hvis dette ikke er muligt at klare så mange opgaver som muligt selv. Hjælpen skal således ydes i henhold til principper, som i højere grad bygger på professionel behovsvurdering end brugervurderet kvalitet $\mathrm{i}$ opgaveløsningen.

Med vægt på brugerdefineret service kan frit valg af leverandør tænkes at betyde en forskydning og nedprioritering af væsent- lige socialpolitiske principper i ældreplejen. Samtidig lægges der afstand til bestræbelser på at styrke faglighed, hvilket hidtil er kommet til udtryk gennem den sociale servicelov samt opbygningen af hjemmehjælpernes professionalisering gennem de erhvervsfaglige uddannelser på området.

\section{"Omsorgskode" og "servicekode» i den kommunale organisation}

Der kan i historisk perspektiv identificeres forskellige faser i hjemmehjælpens udvikling og opbygning - faser, som er betinget af samfundets værdier, ressourcer og prioriteringer i en given tid (Daatland 1997, Dahl 2000, Nordström 2000). I den nuværende omstilling til frit valg kan forskellige værdier ligeledes forventes at være i spil, når private aktører med deres kundeorientering udfordrer den kommunale relativt uniforme organisation, som overvejende har bygget på omsorgstraditionen .

Vi har i det foregående vist dobbeltheden i den gældende lovgivning mellem serviceorientering og princippet om hjælp til selvhjælp, og den kan forventes at genfindes i den kommunale organisation, som har til opgave at føre de socialpolitiske målsætninger ud i livet. Serviceorientering i form af frit leverandørvalg lægger vægt på brugerindflydelse, mens hjælp til selvhjælp tager afsæt i faglige behovsvurderinger - indførelsen af hjælp til selvhjælp er netop blevet anset for at have styrket professionalisering af hjemmehjælp (Dahl 2000, Swane 2003). Vi kan spore en tvetydighed i de kommunale lederes og visitatorers holdninger til 
henholdsvis "omsorgstradition" og serviceorientering i de fire kommuner, der indgik i analysen. ${ }^{3}$

De kommunale ledere og visitatorer giver udtryk for, at de sætter pris på de kommunalt ansatte hjemmehjælperes faglige kunnen. De vurderer, at den kommunale leverandør har velfungerende og velafprøvede arbejdsgange, specialviden i organisationen og tradition for efteruddannelse og faglig opkvalificering af personale. Medarbejderne har især kompetence $\mathrm{i}$ forhold til kerneydelsen, nemlig personlig pleje. Der er blandt kommunale ledere delte meninger om, hvorvidt tiltagende serviceorientering er en farbar vej til en ny hjemmepleje. Nogle kommunale ledelsesrepræsentanter konstaterer, at ansatte i kommunerne i højere grad burde være orienteret mod "service og kundepleje»: "Frit valg har sat skub $i$ den kommunale hjemmepleje - udvikling, nytoenkning og kvalitetssikring. Den har givet nye udfordringer og forhäbentlig bedre service." Andre ledelsesrepræsentanter mener derimod, at selv om indførelse af frit valg har givet anledning til eftertanke inden for den kommunale hjemmepleje, har de kommunalt ansatte et fagligt forspring, som ikke kan indhentes i den nærmeste fremtid: "De kommunale medarbejdere har taget konkurrencen meget afslappet. Man

3 Vi har valgt at bruge betegnelsen omsorg om den hidtidige kommunale praksis, selv om der er mangelfuld empirisk viden om, hvorvidt hverdagspraksis i kommunerne er præget af omsorg. Dog har Lewinter (1999), Swane (2003) og Schultz-Larsen et al. (2004) antydet det ved at pointere, at vilkårene for omsorg er blevet forringet. har fra starten voeret ret sikker $p a ̊$, at man ikke kunne udkonkurreres. De har haft den holdning, at der ikke var nogen, der kunne levere en bedre service, så det har ikke påvirket deres arbejde. "Der synes således at være et ønske om at bevare nogle af de sider, som den kommunale hjemmehjælp traditionen tro er i besiddelse af samtidig med et ønske om, at medarbejdere er mere "kundeorienterede». Det vil sige, at medarbejderne samtidigt skulle udføre opgaverne både efter serviceprincipper og omsorgsprincipper.

Hvad forstår de kommunale ledere ved service? Service synes at handle om at overholde aftaler, begrænse antallet af hjælpere i det enkelte hjem og imødekommenhed, men derimod ikke en egentlig "magtoverdragelse», hvilket er centralt for servicekonceptet i frit valg (fleksibilitet og borgernes medbestemmelse). Samtidig med, at kommunale ledere ønsker serviceorienterede hjemmehjælpere, udtrykker de bekymring for, at dette hensyn kan undergrave nogle socialpolitiske principper i serviceloven, som de mener, medarbejderne i kommunerne er skolet i. De er i tvivl om, hvorvidt disse principper bliver fulgt af private leverandører, som kommer fra hjemmeserviceområdet, og som derfor ikke nødvendigvis har ansatte med sundhedsfaglig uddannelse. Det kan være vanskeligt for en visitator at forklare en medarbejder, der er fokuseret på at udføre rengøringsopgaven til størst mulig tilfredshed for brugeren, hvorfor brugeren selv skal udføre dele af opgaven for at udvikle eller vedligeholde sin funktionsevne. Desuden er medarbejderne i de private firmaer i et dilemma, hvis de skal arbejde på forskellig måde alt efter, om 
de udfører de "kommunale" opgaver, eller opgaver, som brugeren selv betaler for som tilkøbsydelser. ${ }^{4}$

Men kommunerne kan i en konkurrencesituation med private leverandører også selv møde problemer med at omsætte hjælp til selvhjælp-princippet til praksis. Hvis den kommunale leverandør fastholder det socialpolitiske sigte, kan konsekvensen i den sidste ende være, at brugerne vælger en privat i stedet for den kommunale leverandør. En kommunal leder siger: "I serviceloven ligger det indlejret, at man selv er ansvarlig for at gøre det, man kan. ... Men målene kan kun saettes med brugerens accept, ellers når vi det aldrig. Vi kunne frygte, at brugerne voelger det, der ikke stiller de store paedagogiske krav." Dermed kan den kommunale leverandør for at fastholde og tiltrække brugere føle sig presset til at lægge vægt på serviceaspektet. Frit valg af leverandør kan, når det drejer sig om praktisk hjælp, således komme til at betyde, at hjælpen først og fremmest bliver ydet efter principper om god service, mens forebyggende elementer bliver nedtonet. I så fald kommer hjælpen primært til at kompensere for brugernes mangler, hvilket var et kritikpunkt mod den tidligere lov om social bistand (Ældrekommission 1981).

4 Ifølge fritvalgsordningen kan hjemmehjælpsmodtagerne mod betaling få ekstra ydelser ( $\mathrm{fx}$ rengøring hver 2. uge til at supplere den praktiske bistand, som kommunen har bevilget hver 14. dag) hos en privat leverandør, men ikke fra kommunen.

\section{"Omsorgskode" og "servicekode" hos private leverandører}

Kritikken af forandringer i hjemmehjælpen har bl.a. handlet om, at der sker en tiltagende serviceorientering i forbindelse med indførelse af bestiller/udfører-modellen og privatisering af området (bl.a. Olsson \& Ingvad 2003, Vabø 2003). Men hjemmehjælpens "servicepraksis" har ikke været genstand for systematisk forskning i de nordiske lande.

Da der typisk inden for hjemmehjælpen bliver sat lighedstegn mellem service og privat hjælp, er det af interesse, hvordan de private leverandører taler om hjælpen. Hvilken selvforståelse repræsenterer de, og hvor befinder de sig i forhold til omsorg og service? Tegner der sig et billede af en privat "serviceorienteret, ikke-omsorgsfuld" hjælp, som er tydeligt forskellig fra den hjælp, kommunerne tilbyder? Beskrivelsen her bygger på interview med ledere af private firmaer, som yder praktisk bistand, og som typisk arbejder med ældre med forholdsvis mange ressourcer, idet det primært er disse ældre der har valgt en privat leverandør. Derfor er observationerne i høj grad afhængige af den særlige kontekst, som hjælpen gives $i$.

Talen om arbejdet hos de udvalgte private leverandører synes at bære præg af en »husmoderkultur». Der lægges vægt på kendskab til og ansvarlighed for negne" kunder og vægt på kontinuitet i kunderelationer - dvs. aspekter, som på flere måder kan anses for at være tæt relateret til omsorgsidealet beskrevet tidligere. Der kan ikke på nogen måde identifice- 
res bestræbelser på at "opdrage" ældre gennem aktivering $i$ form af krav om deltagelse i udførelsen af opgaver. Dermed er hjælp til selvhjælp-princippet sat ud af kraft. Ældre modtager hjælp, dvs. de deltager ikke selv, og indsatsen karakteriseres som effektiv: "Nu bliver der virkelig gjort rent. "Dermed er der en tydelig rollefordeling mellem de to parter: Den ene udfører opgaver for den anden. Husmoderkulturen i modsætning til den professionelle hjemmehjælp - som kommunerne har opbygget gennem en årrække - kommer endvidere til udtryk gennem de private leverandørers ansættelsespolitik. Flere leverandører foretrækker at ansætte "modne damer" uden at lægge vægt på uddannelsesmæssige krav ved ansættelsen. ${ }^{5}$ De har erfaret, at disse medarbejdere vækker tillid hos kunderne, og samtidig betyder det mindre udskiftning blandt personalet, hvilket betragtes som en fordel både for kunder og firmaet.

Generelt kan man spore en kundeorienteret tilgang hos de private leverandører, som ved interviewene betoner den private virksomheds styrke i forhold til mat imødekomme kundens behov og til at pleje og tilfredsstille kunden". En tilfreds kunde er for den private leverandør tilstrækkeligt udtryk for at have leveret kvalitet. Ledere af de private leverandører præsenterer privat

5 I princippet skal hjemmehjælperne i Danmark være uddannet som social- og sundhedshjælpere, men i praksis har kommunerne ikkekunnet stille dette som krav til personalet hos private leverandører, da samtlige kommunalt ansatte ikke opfylder dette krav. Derfor er kompetencekravet formuleret som "svarende til hjemmehjælper». hjælp som en positiv modpol til kommunal hjælp, som beskrives som opsplittet og instrumentelt både for modtagere og hjælpere. Lederne fremhæver, at hjælpen skal svare til behovene ${ }^{6}$, hvilket de ikke oplever, at den stramme kommunale visitation i tilstrækkelig grad muliggør: "Man kan ikke få udført opgaverne hverken til vores egen eller aeldres tilfredshed." For de private er udgangspunktet "kundens behov", som lægger op til forhandling med modtageren. De vigtigste elementer ved privat hjælp er, at hjælpen er fleksibel og imødekommende i forhold til modtagerens ønsker, at den gives af fast personale på aftalte tidspunkter, og at kunden informeres om eventuelle ændringer.

I forhold til definitioner af omsorg og service, som lægger vægt på magtrelationen mellem giver og modtager (bl.a. Wærness 1983), vægter hjælpen fra de private leverandører klart serviceaspekt. Dette er i høj grad i tråd med målsætningerne ved frit valg, som sætter brugerne i centrum (L 130). Men samtidig kan der ses tegn på elementer af situationel omsorg ved hjælpen. Privat hjælp lægger vægt på faste kunderelationer og individuelt hensyn, som bl.a. bygger på kendskab til kunden og ansvarlighed for denne. Ledere af de private leverandører nævner bl.a., hvordan faste relationer giver mulighed for at vurdere ændringer i hjælpmodtagerens tilstand.

6 I den forbindelse er den forretningsmæssige interesse ikke udelukket, men faktisk kunne vi $i k k e$ i undersøgelsen finde belæg for, at de private leverandører forsøgte - sammen med brugerne - at få mere tid til opgaverne. 
Hensynet til klienten synes således ikke alene at betyde serviceorientering, men også ansvar for den andens velbefindende. Vi kan derfor ikke ud fra vores materiale konkludere, at service i den form, som de private leverandører for tiden praktiserer, fortrænger noget ved almenmenneskelig, situationel omsorg. De private leverandørers omsorg har dog mest karakter af "civilsamfundets omsorgu både hvad angår klientrelationer og medarbejdernes kompetencer og betyder dermed en bevægelse mod uformel hiælp (bl.a. Svallfors 1996). Det træder tydeligt frem i vores materiale, at medarbejdernes arbejdsvilkår og faglighed ikke gives opmærksomhed; medarbejderne forventes at blive belønnet gennem tilfredse kunder.

\section{Nye former for hjælp?}

Omsorgens skiftende karakter har været diskuteret i flere undersøgelser, som har omhandlet hjemmehjælp. Der er blevet identificeret forskellige former for omsorgspraksis gennem tiderne bl.a. afhængig af de organisatoriske og uddannelsesmæssige vilkår, hvorunder omsorgsarbejdet udføres (Szebehely 1995, Dahl 2000, Nordström 2000). Det er for tidligt at evaluere den danske fritvalgsordnings virkninger og betydning for hjemmehjælpen bl.a. fordi ordningen har eksisteret $\mathrm{i}$ kort tid, og den har en relativt begrænset udbredelse.

Men det er relevant at stille spørgsmålet, hvilke tendenser "det nye" eventuelt består af. Frit valg er et af svarene på kritikken af, at den offentlige hjælp er for ufleksibel og ulydhør, men betyder frit valg udelukkende, at denne type forhold bliver rettet op? Vores svar er et betinget nej, idet vi mener, at fritvalgsordningen på sigt kan forventes at betyde parallelle former for hjælp især hvad angår praktisk bistand - hver med deres syn på brugere og medarbejdere. Vi diskuterer her til sidst to forhold, der kan være medvirkende til en sådan udvikling.

\section{Brugerekspertise på markedet?}

Frit valg præsenterer ældre som kompetente, selvstændige og målbevidste borgere, som er i stand til at vælge mellem leverandører og at indgå i forhandlinger med personalet om hjælpens indhold. Den forståelse af brugersuverænitet ${ }^{7}$, som er krumtappen i det frie leverandørvalg (jf. bekendtgørelse og vejledning til loven), hviler på antagelser om, at brugerne og den måde, disse vælger på, kan sikre, at de opnår tilfredshed med kvaliteten af ydelsen. I Socialministeriets pjece (2004), som ministeriet vel at mærke har udgivet i samarbejde med Ældresagen (en stærk interesseorganisation), og som visitatorerne bruger til at informere ældre om frit valg, er ældres medbestem-

7 Begrebet beskriver, hvordan der gøres plads til, at brugeren frit træffer valg ud fra kendskabet til egne ønsker og behov. Brugersuverænitet er her inspireret af begreberne "consumer choice" og "consumer direction", som er udviklet i forbindelse med introduktionen af øget (for)brugerstyring i det amerikanske "managed care«-system (Batavia 2002). 
melse udfoldet yderligere: $d u$ [brugeren] og hjemmehjoelperen kan sammen lave frie aftaler om, hvilke opgaver, du ønsker hjemmehjoelperen skal løse. Denne formulering antyder nærmest ubegrænset frihed, selv om der formelt set ikke er mulighed herfor, da ydelsernes omfang og indhold bygger på visitatorens behovsvurdering ud fra de politisk besluttede retningslinjer i kommunen (Blomberg \& Petersson 2003). Men budskabet kan i høj grad fortolkes som en markering af, at det er brugeren, der er eksperten. Andersen (2004) har kaldt denne tendens for brugernes "forpligtelse til frihed".

Der kan argumenteres for, at frit valg med serviceprincippet og fleksibel hjemmehjælp vil styrke ældres selvstændighed og empowerment og dermed medborgerskabet. Men nye undersøgelser bekræfter ikke denne antagelse (bl.a. Ungerson 2004). Det er blevet påpeget som et dilemma, at ældre nutildags skal agere i mange forskellige roller, hvilket de færreste hjælpafhængige ældre kan overskue (Andersen \& Højlund 2004). Derfor fungerer det store flertal ikke i praksis som fritvælgende brugere, og det gør kunder i øvrigt sjældent på markedet bl.a. fordi de har svært ved at indhente information og sammenligne ydelser (Rombach 1997). Ældrebilledet i fritvalgsordningen er langt fra profilen af den gruppe ældre, som faktisk modtager hjemmehjælp i Danmark (Hansen et al. 2002). På dette grundlag er der tendens til, at et mindretal af ældre benytter sig af det frie valg. For denne gruppe ældre bliver hjælpen til en særlig form for serviceydelse.

\section{Tilsidesattelse af faglighed?}

Som nævnt er der i lovgivningen om frit valg en tendens til at negligere betydningen af en faglig ekspertise. Heller ikke Lov om Social service giver konkrete anvisninger på, hvordan hjemmehjælperne skal omsætte hjælp til selvhjælp-princippet i praksis (Swane 2003). Men i modsætning til frit valg indeholder dette princip i lovteksten en klar opfordring til en faglig vurdering, og den har medvirket til professionalisering på området (Wærness 1995, Swane 2003).

Det er blevet påpeget, at den nye organisering med en adskilt bestiller- og udførerfunktion definerer hjemmehjoelperen som udfører af enkeltstående serviceopgaver (bl.a. Vabø 2003). Ifølge en ny dansk undersøgelse (Schultz-Larsen \& Hanning 2004) er der også tegn på, at standardisering og styring af hjemmehjælpsopgaver danner nye rammer for arbejdet. Ledelsesrepræsentanter i de fire kommuner som indgik i analysen, erkender, at personalet er underlagt en svær omstillingsproces, som de ikke selv har indflydelse på. Hjemmehjælperne er i den nye organisering en del af den kommunale leverandør, hvilket giver de ansatte mindre råderum og kompetence i arbejdet bl.a. ved at begrænse hjemmehjælpernes muligheder for faglige behovsvurderinger. Bestiller-udfører-modellen opsplitter ekspertise og bureaukratiserer kommunikationen mellem hjemmehjælpere og visitatorer (Vabø 2003).

Ansættelsespolitikken hos de private leverandører, som udelukkende er godkendt til at udføre praktisk bistand, sammen med lav prioritering af faglig uddannelse og kva- 
lificering synes at fremme efterspørgslen af en generalistmedarbejder parallelt med tidligere tids husmoder som forbillede for hjemmehjælperen. De mindre private leverandører er presset både af brugerne og af de økonomiske vilkår, hvorfor det kan være svært for dem at investere i medarbejdernes faglige udvikling og uddannelse. Leverandørerne ønsker at maksimere de ansattes ansigt til ansigt-tid hos brugerne, og de har ofte mange deltidsansatte for at imødekomme brugernes ønsker om fleksibilitet. Det betyder i praksis begrænsede muligheder for systematisk kompetenceudvikling på arbejdspladserne, hvilket traditionelt er en væsentlig del af udviklingen af arbejdspraksis på social- og sundhedsområdet. Samtidig udgør de mindre private firmaer ofte meget begrænsede faglige miljøer med få kontakter med social- og sundhedsområdet.

Denne udvikling står i stærk kontrast til, at den hidtidige forskning på området netop har understreget personalets nøgleposition med hensyn til udformning af hjælpen (bl.a. Eliasson-Lappalainen 2003, Nordström 2000). Udviklingen står også i kontrast til bestræbelserne for at styrke fagligheden på området gennem professionalisering, som hviler på systematisk uddannelse og opbygning af social- og sundhedsfaglige miljøer i hjemmehjælpsdistrikterne (Szebehely 1995, Dahl 2000). Det står åbent, hvilke konsekvenser dette på længere sigt vil have for personalets kvalifikationer og engagement samt rekruttering af personale til kommunal hjemmepleje.

\section{Til sidst}

Beslutningstagere forventer ofte, at indførelse af konkurrence vil føre til øget mangfoldighed og brugerindflydelse i velfærdsydelserne, men det kan ikke tages for givet (Rombach 1997). Frit valg i den danske hjemmepleje kan forventes at føre til en vis markedssegmentering og polarisering af hjælpen i kommuner med få udbydere af personlig pleje, hvor de svageste modtager bistand fra den offentlige leverandør, mens de stærkeste modtager hjælp fra private virksomheder. Dermed er der en tendens til selektering af hjælpen (Svallfors 1996, Szebehely 1999) og en større ulighed mellem modtagere. Når det gælder praktisk bistand, synes der at være en drejning mod "forbrugerisme" (Bauman 2002) og prioritering af hjælp, som er af uformel og kompenserende karakter og gives af ikkeprofessionelle hjælpere.

I kommuner med mange modtagere af hjemmehjoelp og flere udbydere med sundhedsfaglig kompetence kan frit valg imidlertid i højere grad forventes at udfordre til en mere «serviceminded» omsorg i såvel offentligt som privat regi og dermed bidrage til større ensartethed $i$ hjælpen. Et muligt scenario er således større mellemkommunale forskelle i hjælpens udformning. 


\section{Referencer}

Andersen, Niels Åkerstrøm (2004) „Kontraktiggørelse af borgeren - om indskiftning af pligt til frihed". Nordiske Organisasjonsstudier vol. $6 \mathrm{nr}$ 1, s. 4-26.

Andersen, Niels Åkerstrøm \& Højlund, Holger (2004) "Den ældre på markedet». Ældre Sagens konference "På vej mod en bedre ældrepleje - Ældrepakken til eksamen«. København.

Ankestyrelsen (2004) Frit valg i oeldreplejen - 22 private leverandørers erfaringer. København: Ankestyrelsen.

Batavia, Andrew (2002) "Consumer direction, consumer choice, and the future of long-term care». Journal of disability policy studies, 13(2), PRO-ED journals, Austin.

Bauman, Zygmunt (2002) Arbejde, forbrugerisme og de nye fattige. København: Hans Reitzel.

Blomberg, Staffan \& Petersson, Jan (2003) „Offentlig äldreomsorg som del i ett socialt medborgarskap». Socialvetenskaplig tidskrift vol. $10 \mathrm{nr} 4$, s. 303-318.

Christensen, Karen (1991) „Hjemmehjælperen - en ny offentlig omsorgsrolle. Et kvindesyn på ældreomsorg". Social Kritiknr. 12, s. 6-18.

Christensen, Karen (1997) Omsorg og arbejde. En sociologisk studie af aendringer $i$ den hjemmebaserede omsorg. Universitetet i Bergen: Sosiologisk Institutt.

Daatland, Svein Olav (1997) (red.) De siste årene. Eldreomsorgen i Skandinavia 1960-95. NOVArapport 22/97. Oslo:NOVA.

Dahl, Hanne Marlene (1999) »Hjemmehjælpen, husmoderen \& den professionelle». Social Kritiknr. 63, s. 38-47.

Eliasson, Rosmari (1995) Forskningsetik och perspektivval. Lund: Studentlitteratur. (Først udgivet i 1987)

Eliasson, Rosmari (1996) (red.) Omsorgens skiftningar. Begreppet, vardagen, politiken, forskningen. Lund: Studentlitteratur.

Eliasson-Lappalainen, Rosmari (2003) »En reseberättelse: fyra städer, fyra arbetsdagar». I Marta Szebehely (red.) Hemhjälp i Norden - illustrationer och refleksioner. Lund: Studentlitteratur.
Eriksen, Tine Rask (2000) "Det moderne plejearbejde og omsorgsbureaukratierne». Grus vol. 21 nr 61, s. 40-57.

Graham, Hilary (1993) "Social Divisions in Caring". Women's Studies International Forum vol.16 nr 5, s. 461-470.

Grönroos, Christian (2000) Service Management and Marketing. A customer relationship management approach. Chichester: John Wiley \& Sons.

Hansen Eigil Boll, Milkær Lone, Swane Christine E., Iversen Christine Lindrum \& Rimdal Brian (2002) Mange boekke små - om hjoelp til svoekkede oeldre. København: FOKUS.

Lewinter, Myra (1999) Spreading the burden of gratitude - elderly between family and state. Københavns universitet: Sociologisk institut.

Lov 130 af 28.februar 2002: Forslag til lov om ændring af lov om social service, lov om retssikkerhed og administration på det sociale område og lov om individuel boligstøtte. (Frit valg af leverandør af personlig og praktisk hjælp).

Lov om retssikkerhed og administration på det sociale område: Lov nr. 453 af 10/6 1997, jf. lovbek. Nr. 697 af 5/8 2003 senest ændret ved lov nr. 1168 af 19/12 2003§1.

Motevasel, Ingrid N. (2000) Män, kvinnor \& omsorg. En studie av omsorg som begrepp och handling i mans- och kvinnodominerade yrken. Lund: Universitetstryckeriet.

Nordström, Monica (2000) Hemtjänsten. Organisering, myndighetsutövning, möten och arbete. Lund: Studentlitteratur.

Olsson, Eric \& Ingvad, Bengt (2003) „Omorganisering i den offentlige sektor i Sverige». Socialpolitiknr 2, s. 28-34.

Qvarsell, Roger (1991) Vårdens idéhistoria. Stockholm: Carlssons bokförlag.

Rombach, Björn (1997) Den marknadslika kommunen - en effektstudie. Stockholm: Nerenius \& Santérus Förlag.

Schultz-Larsen, Kirsten \& Hanning, Susanne (red.) (2004) Den danske oeldrepleje under forandring. En kontrolleret, randomiseret inter- 
ventionsundersøgelse i 36 kommuner. Københavns Universitet: Institut for Folkesundhedsvidenskab.

Socialministeriet (1998) Supplement til vejledning af6. marts 1998 om sociale tilbud til oeldre m.fl. om Bekendtgørelse om kvalitetsstandarder m.v. for hjoelp efter $\$ \$ 71$ og 72 i lov om social service. Vejledning nr. 83 af 09/06/1998.

Socialministeriet og Ældre Sagen (2004): Frit valg og fleksibel hjemmehjoelp. Pjece. København: Socialministeriet.

Svallfors, Stefan (1996) Välfärdsstatens moraliska ekonomi. Umeå: Boréa.

Swane, Christine E. (2003) »Hjälp till självhjälp som strategi i hemtjänsten". I Marta Szebehely (red.) Hemhjälp i Norden - illustrationer och refleksioner. Lund: Studentlitteratur.

Szebehely, Marta (1995) Vardagens organisering. Om vårdbiträden och gamla $i$ hemtjänsten. Lund: Arkiv förlag.

Szebehely, Marta (1999) „Omsorgsarbetets olika former: Nya klasskillnader och gamla könsmönster i äldreomsorgen". Sociologisk Forskning nr 1, s. 7-32.

Szebehely, Marta (2003) (red.) Hemhjälp i Norden - illustrationer och refleksioner. Lund: Studentlitteratur.
Timm, Helle (2000) "Omsorg i et hverdagslivsperspektivw. Grus vol. 21 nr 61, s. 74-87.

Ungerson, Clare (2004) „Whose empowerment and independence? A cross-national perspective on 'cash for care' schemes". Ageing \& Society $24 \mathrm{~s}$. 189-212.

Vabø, Mia (2003) "Mellan traditioner och trender". I Marta Szebehely (red.) Hemhjälp i Norden - illustrationer och refleksioner. Lund: Studentlitteratur.

Wærness, Kari (1983) Kvinnor och omsorgsarbete. Stockholm: Prisma. (norsk i 1982)

Wærness, Kari (1995) „En offentlig tjeneste I spenningsfeltet mellom ulike kulturer". I Stina Johansson (red.) Sjukhus och hem som arbetsplats. Stockholm: Universitetsforlaget.

Wærness, Kari (1996) „Omsorgsrationalitet». I Rosmari Eliasson (red.) Omsorgens skiftningar. Begreppet, vardagen, politiken, forskningen. Lund: Studentlitteratur.

Zeithaml Valarie A., Parasuraman A. \& Berry Leonard L. (1990) Delivering Ouality Services. Balancing Customers Perceptions and Expectations. New York: The Free Press.

Ældrekommissionen (1981) De aldres vilkair. København: Ældrekommissionens 2. delrapport.

\section{Summary}

\section{From care to service-a new orientation in home help?}

Modernization of elder care in Denmark has tendencies similar to what is seen in the other Nordic countries, including increased market orientation and privatisation of services. Since 1 January 2003 citizens granted public home help in principle have had the option to choose a private provider in all municipalities. In practice at least one private provider of home help was approved in about $70 \%$ of the municipalities by spring 2004. In these municipalities about 10\% of the users have chosen a private provider for domestic tasks.

This article discusses the consequences

Eskelinen, Boll Hansen \& Frederiksen: Fra omsorg til service - nyorientering i hjemmeplejen via frit valg? 
of these changes in relation to the content of help. Introducing free choice as a model means that the current social legislation in Denmark contains partly contradictory elements. The principle of free choice underlines users' expectations and preferences and thereby views users as experts, whereas the principle of help-to-self-help emphasizes professional assessment. As a consequence, private providers at the front line seem to place great weight on the former principle (service), as opposed to municipal providers who traditionally tend to pro- mote the latter principle (care). The article illustrates a general tendency that the principle of help-to-self-help comes to play a minor role in the provision of home help. At the same time, informal non-professional care seems to make progress.

In summary, it is essential to analyse the further development in the content and orientation of home help both from the users and the professionals' points of view. The concepts of care and service are most useful when analysing the dilemmas of practice. 